\title{
A Critical Review on Plant Growth Promoting Rhizobacteria
}

Prathap M and Ranjitha Kumari BD*

Department of Plant Science, Bharathidasan University, Tiruchirappalli 620 024, Tamil Nadu, India

\begin{abstract}
The microorganisms with the aim of improving nutrients availability for plants is an important practice and necessary for agriculture. During the past couple of decades, plant growth-promoting rhizobacteria (PGPR) will begin to replace the use of chemicals in agriculture, horticulture, silviculture, and environmental cleanup strategies. Scientific researches involve multidisciplinary approaches to understand adaptation of PGPR, effects on plant physiology and growth, induced systemic resistance, biocontrol of plant pathogens and biofertilization. This is due to the emerging demand for dependence diminishing of synthetic chemical products, to the growing necessity of sustainable agriculture within a holistic vision of development and to focalize environmental protection. The PGPR are naturally occurring soil bacteria that aggressively colonize plant roots and benefit plants by providing growth promotion. Inoculation of crop plants with certain strains of PGPR at an early stage of development improves biomass production through direct effects on roots and shoots growth. In this review, we have discussed about rhizobacteria which act as PGPR, mechanisms and the desirable properties exhibited by them.
\end{abstract}

Keywords: Plant growth promoting rhizobacteria; Agriculture crop production; Biofertilizer

\section{Introduction}

The rhizosphere is a nutrient-rich habitat and harbors a huge variety of bacteria and fungi that each can have neutral, beneficial or deleterious effects on the plant [1]. Some of these organisms can improve plant growth by different mechanisms [2,3]. Fluorescent Pseudomonas and Trichoderma species are important groups of plant growth-promoting microorganism reported to protect plants against pathogens by evolving various mechanisms such as antagonism, competition and Induced systemic resistance (ISR) [4-8]. Rhizosphere colonization by certain PGPR and plant growth-promoting fungi (PGPF) can elicit ISR [4,5,7,9-11]. Induced systemic resistance (ISR) triggered by plant growth-promoting fungi (PGPFs) and Plant growth promoting rhizobacteria (PGPR) confers a broad-spectrum resistance that is effective against different types of pathogens [3].

There are numerous reports of plant growth and yield stimulation by beneficial soil microorganisms $[12,13]$. Plant growth promoting rhizobacteria (PGPR) is one among the most effective and best studied soil microorganisms which can promote plant performance. The PGPR can be classified as extracellular bacteria (existing in the rhizosphere, on the root surface or in the spaces between cells) and intracellular bacteria (mainly $\mathrm{N}_{2}$ fixing bacteria) [14].

The PGPR have been demonstrated to increase growth and productivity of many commercial crops including rice [15], Wheat [16], cucumber [17], maize [18], cotton [19], black pepper [20] and banana [21]

\section{Role of PGPR}

The Plant growth promoting rhizobacteria, compost and chemical fertilizers significantly affect the growth and yield of different crops. A novel approach could be that composted material may be converted into a value added product such as an effective biofertilizer by blending with PGPR which are free living soil bacteria that can either directly or indirectly facilitate rooting [22] and growth of plants [22,23].

There are several mechanisms by which PGPR effect plant growth such as ability to produce various compounds (phytohormones, organic acids, siderophores), fix atmospheric nitrogen, solubilize phosphate and produce antibiotics that suppress deleterious rhizobacteria, and production of biologically active substances or plant growth regulators (PGRs) is one of the major mechanisms through which PGPR influence the plant growth and development [24].

Plant growth promoting rhizobacteria, having multiple activities directed toward plant growth promotion vis-a-vis exhibiting bioremediating potentials by detoxifying pollutants like, heavy metals and pesticides and controlling a range of phytopathogens as biopesticides, have shown spectacular results in different crop plants has been observed following PGPR applications (Table 1). The productive efficiency of a specific PGPR may be further enhanced with the optimization and acclimatization according to the prevailing soil conditions [25].

The bacteria lodging around/in the plant roots (rhizobacteria) are more versatile in transforming, mobilizing, solubilizing the nutrients compared to those from bulk soils [34]. Therefore, the rhizobacteria are the dominant deriving forces in recycling the soil nutrients and consequently, they are crucial for soil fertility [35].

\section{Physiochemical Characterization of PGPR}

PGPR are free-living bacteria and some of them invade the tissues of living plants and cause unapparent and symptomatic infections [36], when applied to seeds or crops, enhance the growth of the plant or reduce the damage from soil-borne plant pathogens [5].

Rhizobacteria that exert beneficial effects on plant growth and development are referred to as PGPR. In last few decades a wide

*Corresponding author: B.D. Ranjitha Kumari, Department of Plant Science, Bharathidasan University, Tiruchirappalli 620 024, Tamil Nadu, India, Tel: 91-94438 34636; E-mail: ranjithakumari2004@yahoo.co.in

Received August 09, 2014; Accepted December 20, 2014; Published December 25,2014

Citation: Prathap M, Ranjitha Kumari BD (2015) A Critical Review on Plant Growth Promoting Rhizobacteria. J Plant Pathol Microb 6: 266. doi:10.4172/21577471.1000266

Copyright: @ 2015 Prathap M, et al. This is an open-access article distributed under the terms of the Creative Commons Attribution License, which permits unrestricted use, distribution, and reproduction in any medium, provided the original author and source are credited. 


\begin{tabular}{|c|c|c|c|c|}
\hline PGPR & Plant & Conditions & Results of addition of bacteria to plants & Reference \\
\hline $\begin{array}{l}\text { Pseudomonas sp. } \\
\text { PS1 }\end{array}$ & $\begin{array}{l}\text { Greengram (Vigna radiate (L.) } \\
\text { wilczek }\end{array}$ & Pots & $\begin{array}{l}\text { Significantly increased plant dry weight, nodule nubers, total chlorophyll } \\
\text { content, leghaemoglobin, root } N \text {, shoot } N \text {, root } P \text {, shoot } P \text {, seed yield and seed } \\
\text { protein }\end{array}$ & [26-28] \\
\hline $\begin{array}{l}\text { Bradyrhizobium } \\
\text { MRM6 }\end{array}$ & $\begin{array}{l}\text { Greengram (Vigna radiate (L.) } \\
\text { wilczek) Soybean, Wheat }\end{array}$ & Pots & $\begin{array}{l}\text { When herbicide tolerant Rhizobium strain MRP1 was used with herbicide, it } \\
\text { increased the growth parameters at all tested concentrations of herbicides } \\
\text { (quizalafop-p-ethyl and clodinafop) }\end{array}$ & {$[29,30]$} \\
\hline $\begin{array}{l}\text { Pseudomonas sp. } \\
\text { Paenibacillus } \\
\text { polymyxa }\end{array}$ & $\begin{array}{l}\text { Pepper } \\
\text { Zea mays L. (maize) }\end{array}$ & $\begin{array}{l}\text { Fields } \\
\text { Gnotobiotic } \\
\text { conditions }\end{array}$ & $\begin{array}{l}\text { Significantly increased soil enzyme activities, total productivity, and nutrient } \\
\text { uptake. } \\
\text { Significantly increased the biomass of plants and elicited induced systemic } \\
\text { resistance against bacterial spot pathogen } \\
\text { Xanthomonas axonopodis pv. } \\
\text { Vesicatoria untreated plants. }\end{array}$ & $\begin{array}{l}{[31]} \\
{[32]}\end{array}$ \\
\hline $\begin{array}{l}\text { Enterobacter } \\
\text { sakazaki 8MR5 }\end{array}$ & & Pots & Inoculation increased growth parameters & [33] \\
\hline
\end{tabular}

Table 1: Examples of plant growth promoting rhizobacteria tested for various crop types.

group of bacterial species including of Pseudomonas, Azospirillum, Azotobacter, Klebsiella, Enterobacter, Alcaligens, Arthrobacter, Burkholderia, Bacillus and Serratia have reported to enhance plant growth $[36,37]$. The PGPR can effect plant growth by producing and releasing secondary metabolites and facilitate the availability and uptake of certain nutrient from the root environment [38]. Unfortunately, the interaction between associative PGPR and plants can be unstable. The good results obtained from in vitro assays cannot be always dependably reproduced under field conditions [39].

The rhizobacterial population was slightly affected by NickelCadmium exposure. However, majority of the isolated strains for both the rhizosphere possessed one or more PGP traits. Isolates tolerant to elevated levels of heavy metals and test bacterium P35 are outstanding for PGP potential. Selection of microorganisms both metal tolerant and efficient in producing PGP compounds can be useful to speed up the recolonization of the plant rhizosphere in polluted soils [40].

The presence of such growth promoting rhizoflora accountable for the beneficial effects on crop growth and yield. The significance of the study could be stated as the potential of these IAA producing isolates and optimization study for IAA production will flourish the growth and ultimately IAA production in the field and prevent environmental pollution by avoiding excessive applications of industrially produced fertilizers to cultivated fields [41].

\section{PGPR as a Biofertilizer}

Bacterial siderophores from $\mathrm{C} 138$ are most effective in supplying $\mathrm{Fe}$ to iron-starved tomato plants when delivered to the roots, independent of the bacterial presence. Furthermore, results are similar or even better than with full Hoagland solution, representing a promising candidate to develop an organic Fe chelator. The short period is needed for fermentation appears as an asset for economic feasibility. In summary, strain C138 tested in this experiment can serve as an effective organic biofertilizer [42].

The plant-PGPR cooperation plays a major role by enhancing growth and health of widely diverse plants. That plant PGPR independently produced IAA has also been revealed. It is obviously a step forward in our understanding of plant-PGPR cooperation but it does not fully clarify the bacterial functions and plant hormonal networks involved in components of hormonal pathways [43].

Phytohormone-producing Bacillus sp., WhIr-15 and B. subtilis WhIr-12, isolated in the present study, have potential at field level to improve wheat productivity and may be helpful in the formulation of an effective biofertilizer for wheat $[25,44]$. Expected to replace the chemical fertilizers, pesticides and artificial growth regulators which have numerous side effects to sustainable agriculture.

Multifaceted bacterium of Bacillus amyloliquefaciens was improved growth, yield and nutrition of soybean through the contributions of the bacteria mediated induced mechanisms/ processes in the rhizosphere of the soybean and also as a broad-spectrum bioinoculant for soybean cultivation in India [45].

\section{PGPR as a Biocontrol}

The plant growth-promoting traits by a comparative genomics analysis of four representative pseudomonad PGPR strains. The genes that were conserved among the different Pseudomonas species have provided clues to the common characteristics of pseudomonad PGPR, such as rhizosphere competence traits (nutrient catabolism and transport, resistance to various environmental stresses and rhizosphere colonization). Recently reported genome of $P$. chlororaphis, together with other sequenced strains of different species of pseudomonad PGPR, provides insights into the genetic basis of diversity and adaptation to specific environmental nich es. Genetic modification may accelerate the commercialization of PGPR as biocontrol agents, which could further contribute to sustainable development of agriculture [46].

The ability of bacterial siderophores and antibiotics to suppress phytopathogens could be the significant agronomic importance. Both mechanisms have essential functions in microbial antagonism but also the mechanisms leads to elicit induced resistance. Resistance-inducing and antagonistic rhizobacteria might be useful in formulating new inoculants, offering an attractive alternate of environmentally friendly biological control of plant disease and improving the cropping systems into which it can be most profitably applied [47].

The evolution of T3SSs in bacteria with this knowledge will contribute in the development of various biotechnological applications involving the design of efficient strategies to control plant diseases, the exploitation of T3SS as scaffold for protein delivery into eukaryotic cells, the improvement of the symbiotic properties of rhizobial species or even the expansion of the symbiotic potential towards the nonleguminous plants of agriculture importance [48].

The selected bacterial strains are feasible to be used for development of plant growth promoting or biocontrol inoculants, together with other plant growth promoting microbes [49].

\section{Stress Study of PGPR}

An ideal selection of bioagents having abiotic stress tolerance and proven antagonistic activity for their consistent performance under field conditions [50]. 
Water stress caused higher antioxidative activity and the highest concentration CAT and GPX activity were in W3 (Three levels of water stress $W_{1}=80$ (control), $W_{2}=60$ and $W_{3}=40 \%$ of the field capacity (FC)) treatments. However by increasing water stress from control to W3, chlorophyll content in leaves was increased but $\mathrm{Fv} / \mathrm{Fm}$ and ascorbate peroxidase (APX) activity decreased. Inoculation with rhizobacteria could be efficiently used to improve growth, antioxidant status and photosynthetic pigments in basil under water stress. Pseudomonades sp. under water stress, significantly improved CAT enzyme activity in the leaves and increased it. But the highest GPX and APX activity and chlorophyll content in leaves under water stress was in combination of three bacterial species (Pseudomonades sp., Bacillus lentus, Azospirillum brasilens) [51].

\section{PGPR as a Bioformulation}

The new challenge in the new millennium is to produce more and more food from shrinking per capita arable land, keeping the environment safe. As agricultural production intensified over the past few decades, producers became more and more dependent on agrochemicals. Chemical fertilizers and pesticides are presently accumulating in the environment harming the ecosystem, causing pollution and spreading disease [52]. Therefore, the urgent need of biological agents is accepted worldwide. Interest in biological control of plant pathogens has increased considerably over the past years, partly as a response to public concern about the use of hazardous chemical pesticides, but also because it may provide control of diseases that cannot or only partially be managed by other control strategies $[53,54]$.

The biocontrol agents, plant growth promoting rhizobacteria such as Pseudomonas spp. and Bacillus spp. have shown activity in suppressing the fungal infection and promoting growth characteristics [55]. When PGPR are mixed with some other strains, or other bacteria or fungal antagonists the biocontrol efficacy is increased [56]. Thus, the objective of this study was study of new bioformulations efficacy in promoting growth characteristics of cotton seedlings.

\section{Conclusion}

The plant growth promoting phenomenon can be attributed to the ability of the isolate to produce IAA, as IAA positively influences root growth and development, thereby enhancing nutrient uptake [16]. It is a well established fact that improved phosphorous nutrition influences overall plant growth and root development [57]. Plant microbe interaction in Rhizosphere must increase before we can presume that utilization of PGPR as biofertilizers will determine a sustainable promotion of host plants growth. Combinations of beneficial bacterial strains that interact synergistically are currently being devised and numerous recent studies have shown a promising trend in the field of inoculation technology. PGPR are excellent model systems which can provide biotechnologist with novel genetic constituents and bioactive chemicals having diverse uses in agriculture and environmental sustainability.

\section{References}

1. Berendsen RL, Pieterse CM, Bakker PAHM (2012) The rhizosphere microbiome and plant health. Trends in Plant Science 17: 478-486.

2. Lugtenberg B, Kamilova F (2009) Plant-growth-promoting rhizobacteria. Annual Review of Microbiology 63: 541-556.

3. Van der Ent S, Van Wees SC, Pieterse CMJ (2009) Jasmonate signaling in plant interactions with resistance-inducing beneficial microbes. Phytochemistry 70: $1581-1588$

4. Harman GE, Howell CR, Viterbo A, Chet I, Lorito M (2004) Trichoderma species-opportunistic, avirulent plant symbionts. Nature Reviews 2: 43-56.
5. Kloepper JW, Leong J, Teintze M, Schroth MN (1980) Enhanced plant growth by siderophores produced by plant growth-promoting rhizobacteria. Nature 286: 885-886.

6. Marx J (2004) The roots of plant-microbe collaborations. Science 304: 234-236.

7. Van Loon LC, Bakker PAHM, Pieterse, CMJ (1998) Systemic resistance induced by rhizosphere bacteria. Annual Review of Phytopathology 36: 453483

8. Vinale F, Sivasithamparam K, Ghisalberti EL, Marra R, Woo SL, et al. (2008) Trichoderma-plant-pathogen interactions. Soil Biology and Biochemistry 40: $1-10$.

9. Bent E (2006) Induced systemic resistance medidated by plant growthpromoting rhizobacteria (PGPR) and fungi (PGPF). In: Tuzun S, Bent E (eds.) Multigenic and Induced Systemic Resistance in Plants. Springer, US. 225-258.

10. Shoresh M, Harman GE, Mastouri F (2010) Induced systemic resistance and plant responses to fungal biocontrol agents. Annual Review of Phytopathology 48: $21-43$.

11. Van Wees SCM, Van der Ent S, Pieterse CMJ (2008) Plant immune responses triggered by beneficial microbes. Current Opinion in Plant Biology 11: 443-448.

12. Adesemoye AO, Torbert HA, Kloepper JW (2008) Enhanced plant nutrient use efficiency with PGPR and AMF in an integrated nutrient management system. Canadian Journal Microbiology 14: 876-886.

13. Adesemoye AO, Kloepper J (2009) Plant-microbes interactions in enhanced fertilizer-use efficiency. Applied Microbiology and Biotechnology 14: 1-12.

14. Berg G (2009) Plant-microbe interactions promoting plant growth and health perspectives for controlled use of microorganisms in agriculture. Applied Microbiology and Biotechnology 14: 11-18.

15. Ashrafuzzaman $M$, Hossen FA, Razi Ismail M, Hoque MA, Zahurul Islam M et al. (2009) Efficiency of plant growth-promoting rhizobacteria (PGPR) for the enhancement of rice growth. African Journal of Biotechnology 8: 1247-1252.

16. Khalid A, Arshad M, Zahir ZA (2004) Screening plant growth promoting rhizobacteria for improving growth and yield of wheat. Journal of Applied Microbiology 96: 473-480.

17. Maleki M, Mostafee S, Mokhaternejad L, Farzaneh M (2010) Characterization of Pseudomonas fluorescens strain CV6 isolated from cucumber rhizosphere in Varamin as a potential biocontrol agent. Austrlian Journal of Crop Science 4: 676-683.

18. Sandhya V, Ali SKZ, Grover M, Reddy G, Venkatswarlu B (2010) Effect of plant growth promoting Pseudomonas spp. on compatible solutes, antioxidant status and plant growth of maize under drought stress. Plant Growth Regulator 62: $21-30$.

19. Anjum MA, Sajjad MR, Akhtar N, Qureshi MA, lqbal A, et al. (2007) Response of cotton to plant growth promoting rhizobacteria (PGPR) inoculation under different levels of nitrogen. Journal of Agricultural Research 45: 135-143.

20. Dastager SG, Deepa CK, Pandey A (2010) Potential plant growth promoting activity of Serratianematophila NII-0.928 on black pepper (Piper nigrum L.). World Journal of Microbiology and Biotechnology 27: 259-265.

21. Mia MAB, Shamsuddin ZH, Wahab Z, Marziah M (2010) Effect of plant growth promoting rhizobacterial (PGPR) inoculation on growth and nitrogen incorporation of tissue-cultured Musa plantlets under nitrogen-free hydroponics condition. Australian Journal of Crop Science 4: 85-90.

22. Mayak S, Tirosh, T, Glick BR (1999) Effect of wild-type and mutant plant growth promoting rhizobacteria on the rooting of mung bean cuttings. Journal of Plant Growth Regulation 18: 49-53.

23. Glick BR, Karaturovic DM, Newell PC (1995) A novel procedure for rapid isolation of plant growth promoting Pseudomonads. Canadian Journal of Microbiology 41: 533-536.

24. Arshad M, Frankenberger WT (1998) Plant growth regulating substances in the rhizosphere: microbial production and functions. Advances in Agronomy 62: 46-151.

25. Ahemad M, Kibret M (2014) Mechanisms and applications of plant growth promoting rhizobacteria: Current perspective. Journal of King Saud University - Science 26: 1-20.

26. Ahemad M, Khan MS (2012d) Alleviation of fungicide-induced phytotoxicity in greengram [Vigna radiate (L.) Wilczek] using fungicide-tolerant and plant 
growth promoting Pseudomonas strain. Saudi Journal of Biological Science 19: $451-459$.

27. Ahemad M, Khan MS (2011b) Pseudomonas aeruginosa strain PS1 enhances growth parameters of greengram [Vigna radiate (L.)Wilczek] in insecticidestressed soils. Journal of Pest Science 84: 123-131.

28. Ahemad M, Khan MS (2010a) Phosphate-solubilizing and plant-growthpromoting Pseudomonas aeruginosa PS1 improves green-gram performance in quizalafop-p-ethyl and clodinafop amended soil. Archives of Environmental Contamination and Toxicology 58: 361-37.

29. Ahemad M, Khan MS (2012e) Productivity of greengram in tebuconazolestressed soil, by using a tolerant and plant growth promoting Bradyrhizobium sp. MRM6 strain. Acta Physiologiae Plantarum 34: 245-254.

30. Ahemad M, Khan MS (2011c) Insecticide-tolerant and plant growth promoting Bradyrhizobium sp. (vigna) improves the growth and yield of greengram [Vigna radiata(L.) Wilczek] in insecticide-stressed soils. Symbiosis 54: 17-27.

31. Sharma SK, Johri BN, Ramesh A, Joshi OP, Prasad SVS (2011) Selection of plant growth-promoting Pseudomonas spp. that enhanced productivity of soybean-wheat cropping system in central India. Journal of Microbiology and Biotechnology 21: 1127-1142.

32. Phi, Quyet.-Tien, Yu-Mi P, Keyung-Jo S, Choong-Min R, et al. (2010) Assessment of root-associated Paenibacillus polymyxa groups on growth promotion and induced systemic resistance in pepper. Journal of Microbiology and Biotechnology 20: 1605-1613.

33. Babalola OO, Osir EO, Sanni A, Odhaimbo GD, Bulimo WD (2003) Amplification of 1-aminocyclopropane-1-carboxylic (ACC) deaminase from plant growth promoting rhizobacteria in Striga -infested soils. African Journal of Biotechnology 2: 157-160.

34. Hayat R, Ali S, Amara U, Khalid R, Ahmed I (2010) Soil beneficial bacteria and their role in plant growth promotion: a review. Annals of Microbiolog 60 579-598.

35. Glick BR (2012) Plant Growth-Promoting Bacteria: Mechanisms and Applications. Hindawi Publishing Corporation,Scientifica.

36. Sturz AV, Nowak J (2000) Endophytic communities of rhizobacteria and the strategies required to create yield enhancing associations with crops. Applied Soil Ecology 15: 183-190.

37. Okon Y, Labandera-Gonzalez C (1994) Agronomic applications of Azospirillum an evaluation of 20 years of worldwide field inoculation. Soil Biology and Biochemistry 26: 1591-1601.

38. Zahir ZA, Arshad M, Frankenberger WT (2004) Plant growth promoting rhizobacteria: applications and perspectives in agriculture. Advances in Agronomy 81: 97-168.

39. Zehnder G, Kloepper J, Yao C and Wei G (1997) Induction of systemic resistance against cucumber beetles (Coleoptera: Chrysomelidae) by plan growth-promoting rhizobacteria. Journal of Economic Entomology 90: 391-396.

40. Rathaur P, Ramteke PW, Raja W, John SA (2012) Isolation and Characterization of Nickel and Cadmium Tolerant Plant Growth Promoting Rhizobacteria from Rhizosphere of Withania somnifera. Journal of Biodiversity and Environmental Sciences 6: 253-261.

41. Mohite B (2013) Isolation and characterization of indole acetic acid (IAA) producing bacteria from rhizospheric soil and its effect on plant growth. Journal of Soil Science and Plant Nutrition 13: 638-649.

42. Radzki W, Gutierrez FG, Mañero E, Algar Lucas García JA, García-Villaraco A, et al. (2013) Bacterial siderophores efficiently provide iron to iron-starved tomato plants in hydroponics culture. Antonie van Leeuwenhoek 104: 321-330.

43. Vacheron J, Desbrosses G, Bouffaud M-L, YvanMoënne-Loccoz RT, Muller D, et al. (2013) Plant growth-promoting rhizobacteria and root system functioning. Frontiers in Plant Science 4: 1-19.
44. Baghaeeravari S, Heidarzadeh N (2014) Isolation and characterization of rhizosphere auxin producing Bacilli and evaluation of their potency on wheat growth improvement, Archives of Agronomy and Soil Science 60: 895-905.

45. Sushil K, Sharma Aketi Ramesh, Bhavdish N, Johri (2013) Isolation and Characterization of Plant Growth Promoting Bacillus. amyloliquefaciens Strain Sks_bnj_1and its influence on Rhizosphere Soil Properties and Nutrition of Soybean (Glycine max L. Merrill). Journal of Virology \& Microbiology 1-19.

46. Shen X, Hongbo Hu, HuasongPeng, Wei Wang, Xuehong Zhang (2013) Comparative genomic analysis of four representative plant growth-promoting rhizobacteria in Pseudomonas.BMC Genomics 14: 271.

47. Beneduzi A, Ambrosini A, Luciane Passaglia MP (2012) Plant growth-promoting rhizobacteria (PGPR): Their potential as antagonists and biocontrol agents. Genetics and Molecular Biology 35: 1044-1051.

48. Tampakaki AP (2014) Commonalities and differences of T3SSs in rhizobia and plant pathogenic bacteria. Frontiers in Plant Science 5: 1-19.

49. EvaLaslo, EvaGyorgy, Gyongyver Mara, EvaTamas, BeataAbraham, et al (2012) Screening of plant growth promoting rhizobacteria as potential microbial inoculants. Crop Protection 40: 43-48.

50. Praveen Kumar G, Mir Hassan Ahmed SK, Desai S, Leo Daniel Amalraj E, Abdul Rasul (2014) In vitro screening for abiotic stress tolerance in potent biocontrol and plant growth promoting strains of Pseudomonas and Bacillus spp. International Journal of Bacteriology 1-6.

51. Heidari M, Golpayegani A (2012) Effects of water stress and inoculation with plant growth promoting rhizobacteria (PGPR) on antioxidant status and photosynthetic pigments in basil (Ocimum basilicum L.). Journal of the Saud Society of Agricultural Sciences 11: 57-61.

52. Gerhardson B (2002) Biological substitutes for pesticides. Trends Biotechnology 20: $338-343$

53. Arora NK, Khare E, Naraian R, Maheshwari DK (2008a) Sawdust as a superior carrier for Production of multipurpose bioinoculant using plant growth promoting rhizobial and pseudomonad strains and their impact on productivity of Trifoliumrepense. Current Science 95: 90-94.

54. Arora NK, Khare E, Oh JH, Kang SC, Maheshwari DK (2008b) Diverse mechanisms adopted by fluorescent Pseudomonas PGC2 during the inhibition of Rhizoctonia solani and Phytophthora capsici. World Journal of Microbiology and Biotechnology 24: 581-585

55. Chen C, Bélanger RR, Benhamou N, Paulitz TC (2000) Defense enzymes induced in cucumber roots by treatment with plant growth-promoting rhizobacteria (PGPR) and Pythium aphanidermatum. Physiological and Molecular Plant Pathology 56: 13-23.

56. Duffy BK, Simon A, Weller DM (1996) Combination of Trichoderma koningii with fluorescent pseudomonads for control of take-all on wheat. Phytopathology 86 : 223-52.

57. Jones DL, Darah PR (1994) Role of rot derived organic acids in the mobilization of nutrients from the rhizosphere. Plant and Soil 16: 247-257. 